\title{
Employment of morphometric variables to assess nutritional condition of Argentine anchovy larvae Engraulis anchoita Hubbs \& Marini, 1935
}

\author{
Empleo de variables morfométricas para determinar la condición nutricional de larvas de anchoíta \\ Argentina Engraulis anchoita Hubbs \& Marini, 1935 \\ Marina V. Diaz ${ }^{1,2}$, Marcelo Pájaro² and Ramiro P. Sánchez ${ }^{2}$ \\ ${ }^{1}$ Consejo Nacional de Investigaciones Científicas y Técnicas (CONICET). Rivadavia 1917, C1033AAV, \\ Ciudad Autónoma de Buenos Aires, Argentina \\ ${ }^{2}$ Instituto Nacional de Investigación y Desarrollo Pesquero (INIDEP), Paseo Victoria Ocampo $N^{\circ} 1$ Escollera Norte, \\ B7602HSA, Mar del Plata, Argentina \\ mdiaz@inidep.edu.ar
}

\begin{abstract}
Resumen.- Las causas más importantes de mortalidad larval son la depredación e inanición. Esta última puede ser estimada mediante el estudio de la condición nutricional. El objetivo del presente estudio fue evaluar la condición nutricional de larvas de E. anchoita empleando técnicas morfométricas en tres áreas del mar Argentino con diferentes características hidrográficas para establecer variaciones regionales e interpoblacionales: área costera de El Rincón, Plataforma Continental y zona de frentes de marea de Península Valdés. Las larvas provenientes de El Rincón presentaron una tasa de crecimiento más elevada (pendiente de la curva de crecimiento $=3,575)$ pero menores índices de condición de Fulton $(15,71$ $\pm 3,58, n=41)$ y Le Cren $(0,63 \pm 0,13, n=41)$ en comparación con los especímenes recolectados en las otras dos zonas $(P<$ 0,001). El análisis de componentes principales empleando variables morfométricas y el peso, mostró la separación de larvas provenientes de El Rincón con respecto a otras capturadas en las restantes áreas. Estos resultados podrían ser explicados como una consecuencia de un incremento en la mortalidad denso dependiente o por competencia por el alimento en el área de El Rincón debido a un año en el que se registró una producción larval excepcionalmente elevada. Nuestros resultados muestran que el uso de las variables morfométricas y el peso permiten hallar diferencias en la tasa de crecimiento y la condición nutricional de las larvas de anchoíta recolectadas en áreas caracterizadas por escenarios oceanográficos diferentes.
\end{abstract}

Palabras clave: Engraulidae, Océano Atlántico sudoccidental, morfometría, análisis de componentes principales

\begin{abstract}
Most important causes of larval mortality are predation and starvation. The latter can be assessed by the measurement of the nutritional condition. The objective of the present study was to evaluate the nutritional condition of $E$. anchoita larvae employing morphometric techniques in three different hydrographic areas of the Argentine sea in order to establish regional and interpopulation variability: El Rincón coastal area, Outer-shelf and Península Valdés tidal front. Sampled larvae from El Rincón coastal area showed a higher growth rate (growth curve slope $=3.575$ ) but had lower weight, and thus low Fulton $(15.71 \pm 3.58, \mathrm{n}=41)$ and Le Cren $(0.63$ $\pm 0.13, \mathrm{n}=41$ ) condition indices, in comparison to specimens from the other two areas $(P<0.001)$. The Principal Component Analysis, employing morphometrical variables and weight, separated larvae from El Rincón from larvae captured in the other areas. These results could be explained as a consequence of an increase in density dependent mortality or food competition in El Rincón due to a year with an exceptional high larvae production. Our results showed that the use of morphometrical variables and weight allow to find differences in growth rate and nutritional condition among anchovy larvae collected in areas characterized by dissimilar oceanographic scenarios.
\end{abstract}

Key words: Engraulidae, southwest Atlantic Ocean, morphometrics, Principal Component Analysis

least two populations of E. anchoita occur separately at approximately $41^{\circ} \mathrm{S}$ : the Northern and the Southern or Patagonian stock (Hansen et al. 1984, Sánchez 1995). During spring the Northern stock is found in coastal sectors off Buenos Aires Province, mostly in waters shallower than $50 \mathrm{~m}$, where massive spawning occurs (Sánchez \& Ciechomski 1995, Pájaro 1998). In contrast, Southern stock spawns in association with a tidal frontal 
system along the Patagonian coast (Sánchez et al. 1996). Anchovy eggs and larvae are found year-long with an abundance peak during spring and summer for the Northern and the Southern population respectively (Ciechomski \& Sánchez 1984).

The Argentine Sea comprises several areas characterized by different oceanographic conditions. Mesoscale fronts are important features of the Argentine shelf, creating a diversity of spawning habitats for adult fish and different breeding conditions for eggs and larvae (Sánchez \& Ciechomski 1995). In frontal zones a nutrient enhancement is usually observed which results in an increased primary and secondary production (Mann \& Lazier 1996). Thus, fronts provide advantages for various types of organisms but could be a disadvantageous zone for others due to nutritional stress (Olson 2002) or predation (Bailey \& Houde 1989, Acha et al. 2004).

The study area of the present investigation includes three different oceanographic zones: El Rincón, Outershelf and the Península Valdés tidal front (Fig. 1). The El Rincón area comprises a coastal estuarine zone and a shallow sea thermal front at the $40-50 \mathrm{~m}$ isobaths, persistent throughout the year (Acha et al. 2004, Lucas et al. 2005). The Outer-shelf extends from the coastal region, limited by the $40 \mathrm{~m}$ isobath, as far as the shelfbreak. In the studied region the shelf-break could be found closer to the 90-100 m isobath. At this depth the encounter of subantartic shelf waters and more saline and cooler waters from the Malvinas current produce a permanent thermohaline frontal structure (Martos \& Piccolo 1988, Acha et al. 2004). The Península Valdés tidal front is observed during spring and summer, showing a thermal discontinuity that defines a boundary between stratified (offshore) and coastal homogeneous waters (Carreto et al. 1986, Glorioso 1987, Acha et al. 2004).

As a consequence of anchovy wide latitudinal spawning range, early developmental stages could be found in areas with different oceanographic regimens, prey concentrations and eventually very close to their tolerance limits of temperature and salinity.

It is known that populations' dynamics of planktonic fishes are affected by the influence of environmental

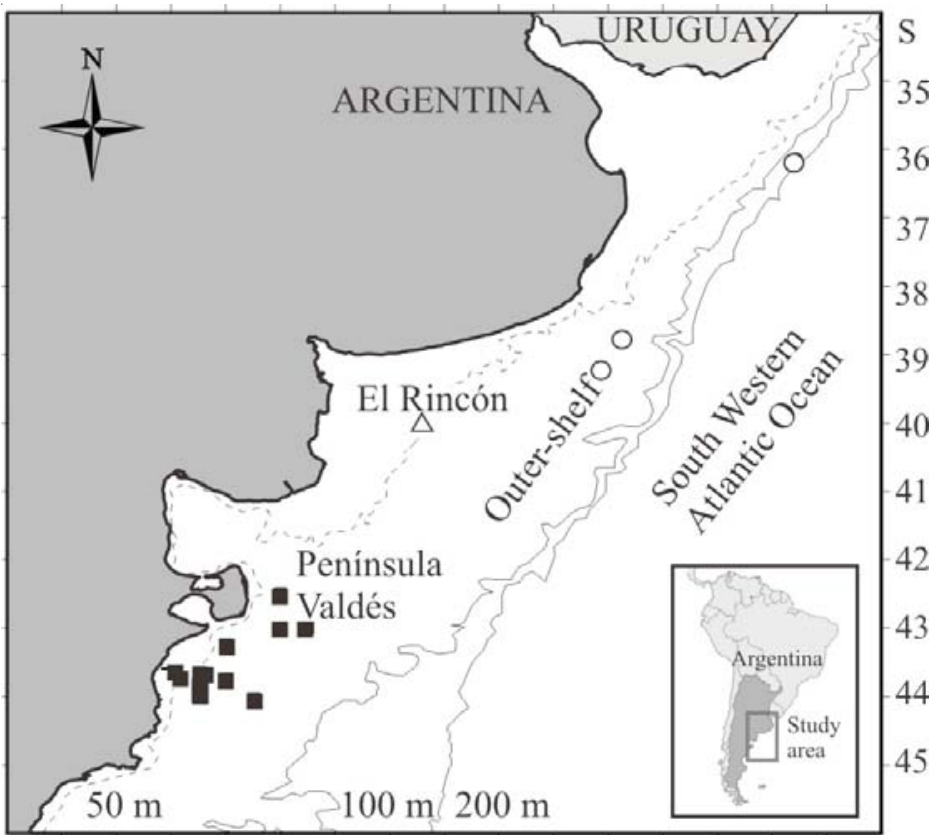

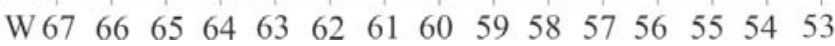

Figure 1

\section{Spatial distribution of sampling stations from different cruises: SM-08/78 $(\Delta)$ to El Rincón area, CC-01/83 (O) to Outer-shelf area and EH-01/83 (ם) to Península Valdés area}

Distribución espacial de las estaciones donde se recolectaron muestras en los diferentes cruceros: SM-08/78 $(\Delta)$ al área de El Rincón, CC-01/83 (O) al área de la Plataforma Continental y EH-01/83 (ם) al área de Península Valdés 
conditions. Even though it is under discussion at which developmental stage recruitment is determined, larval mortality is still considered very important in this concern. Factors affecting survival of young fish are diverse. Many authors agree that main sources of mortality are predation and starvation. In contrast to predation which is difficult to measure, starvation mortality can be assessed by the measurement of the nutritional condition (Ferron \& Leggett 1994). Hjort (1914) suggested that larvae survival might be affected by lack of food during yolk absorption period and transport to unfavourable areas. Mechanisms associated with Hjort's hypotheses (trophodynamics and hydrodynamics) may act together and are probable sources of variability in early-life survival (Houde 2008).

Different criteria have been developed to assess nutritional condition of fish larvae based on the differences that starvation produces in body form (Ehrlich et al. 1976, Theilacker 1978, Powell \& Chester 1985, Frank \& McRuer 1989), condition factor (Ehrlich et al. 1976), chemical cell constituents (Håkanson 1989, Clemmesen et al. 1997) and histological integrity (O’Connell 1976, Theilacker 1978, McFazenden 1997).

Little is known about E. anchoita nutritional condition. Ciechomski et al. (1986) had studied growth in length and condition factor along development of larvae from Northern population, but they had only studied weight-length relationships without taking into account oceanographic features. Other authors had studied anchovy condition in Brazil and Península Valdés employing DNA/RNA ratio (Clemmesen et al. 1997) and histological methods (Sieg 1998). They had found better condition indices in Península Valdés than in Brazil, but they could not relate this fact with hydrographical conditions or prey densities.

The main objective of the present work was to determine if the employment of morphometrical variables and weight allow finding differences in E. anchoita larvae nutritional condition collected in three areas in the Southwestern Atlantic characterized by dissimilar oceanographic features. The main goal of the present study was the employment of a conventional and simple method, such as morphometrics, to assess nutritional condition of E. anchoita larvae.

\section{Material and methods}

\section{Sample collection and laboratory analysis}

Material analyzed came from three cruises made by the INIDEP: SM-08/78 (November 1978) to El Rincón area, CC-01/83 (January 1983) to Outer-shelf area and EH01/83 (January 1983) to Península Valdés area (Fig. 1). It is important to mention that cruises were made during the spawning peak of the species in each area. Sampled larvae were taken with a $330 \mu \mathrm{m}$ mesh Bongo net and fixed in formalin 5\% buffered in sea water. Water temperature $\left({ }^{\circ} \mathrm{C}\right)$ at $2 \mathrm{~m}$ depth was measured with a CTD in each sampling station. An average temperature was calculated for each sampled area employing data from stations where anchovy larvae were taken (Table 1). Standard length (SL) and total dry weight (W) of each larva $(n=356)$ were recorded. Measurements were made under a Wild M5 binocular microscope to the nearest $\mathrm{mm}$. SL was taken from the tip of the snout to the end of the notochord and each larva was assigned to the nearest

\section{Table 1}

Growth curve slope, mean water temperature at $2 \mathrm{~m}$ depth, mean (SD) and median values of Fulton (FCI) and Le Cren (LCCI) Condition indices for Engraulis anchoita larvae

Pendiente de la curva de crecimiento, temperatura media del agua, media (SD) y mediana de los valores de los índices de condición de Fulton (FCI) y Le Cren (LCCI) para larvas de Engraulis anchoita

\begin{tabular}{lccc}
\hline $\begin{array}{l}\text { Area } \\
\text { Cruise code }\end{array}$ & $\begin{array}{c}\text { El Rincón } \\
\text { SM-08/78 }\end{array}$ & $\begin{array}{c}\text { Outer-shelf } \\
\text { CC- 01/83 }\end{array}$ & $\begin{array}{c}\text { P. Valdés } \\
\text { EH-01/83 }\end{array}$ \\
\hline Growth curve slope & 3.575 & 3.291 & 2.827 \\
Mean temp. $\left({ }^{\circ} \mathrm{C}\right)$ & 15.7 & 20.6 & 18.0 \\
Mean FCI $(\mathrm{SD})$ & $15.71(3.58)$ & $30.61(6.77)$ & $29.34(4.54)$ \\
Mean LCCI (SD) & $0.63(0.13)$ & $1.22(0.27)$ & $1.19(0.20)$ \\
Median FCI & 15.26 & 29.92 & 29.51 \\
Median LCCI & 0.60 & 1.17 & 1.17 \\
$\mathrm{~N}$ & 41 & 36 & 279 \\
\hline
\end{tabular}




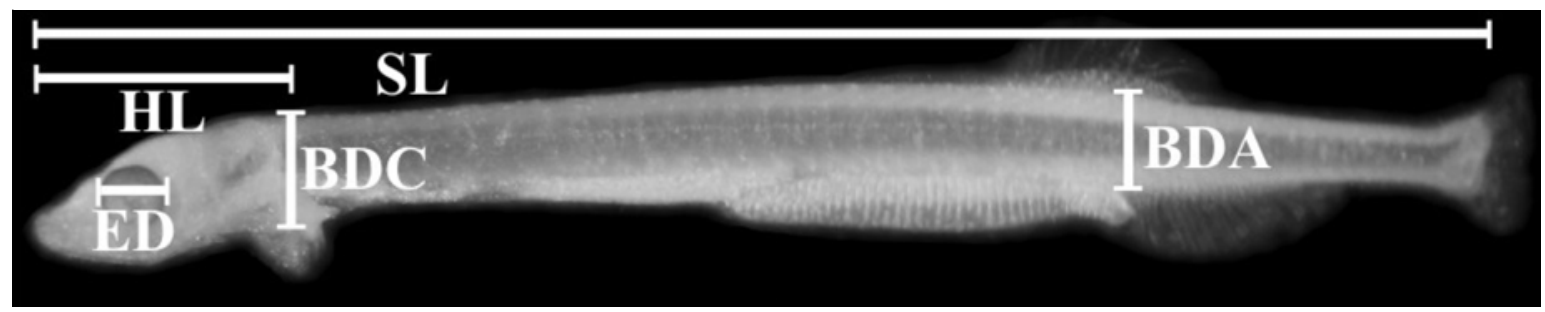

Figure 2

Engraulis anchoita larva (12 mm SL) with location of the morphometrical measurements indicated: standard length (SL), head length (HL), body depth at cleitrum (BDC), body depth at the anus (BDA) and eye diameter (ED)

Larva de Engraulis anchoita (12 mm LS) indicando la ubicación de las mediciones realizadas: longitud estándar (SL), longitud de de la cabeza (HL), anchura del cuerpo a nivel del cleitro (BDC), anchura del cuerpo a nivel del ano (BDA) y diámetro del ojo (ED)

size category. Measurements were made a few months after samplings in order to allow larvae to shrink. No shrinkage corrections were made because only larvae from a restricted size range were employed. Larvae were rinsed in distilled water during $48 \mathrm{~h}$, dried at $60^{\circ} \mathrm{C}$ during $24 \mathrm{~h}$ and weighed to the nearest $\mu \mathrm{g}$ (Cahn 21 electrobalance $\pm 0.0001 \mathrm{mg})$. Additionally, four other morphometric characters were measured on larvae $(\mathrm{n}=$ 109): head length (HL) from the tip of the snout to the cleitrum, body depth at cleitrum (BDC), body depth at the anus (BDA) and eye diameter (ED) measured as the media between the maximal and minimum diameter (Fig. 2).

\section{Data analysis}

All comparisons were made within a restricted body size in order to diminish the effects of allometric growth of body parts during the anchovy larvae development.

Relationship between W and SL for the entire set of data and for each area was described by a power regression model:

$$
W=a S L^{b}
$$

In order to estimate and compare growth rate between cruises, $\mathrm{W}$ and SL were $\log _{\mathrm{e}}$-transformed and slopes were tested for larvae ranged from 11 to $18 \mathrm{~mm}$ SL by a $t$-test for slopes.

Condition was estimated employing Fulton's Condition Index (FCI); calculated with the following equation:

$$
F C I=\frac{W \times 100}{S L^{3}}
$$

This condition index is based on the hypothesis that individuals of higher weight of a certain length are in better condition than those of lower weight (Ciechomski et al. 1986).
Le Cren Condition Index (LCCI) was also employed to estimate larvae condition with the following expression:

$$
L C C I=\frac{W_{o b s}}{W_{\exp }}
$$

where, $\mathrm{W}_{\text {obs }}$ is the observed weight and $\mathrm{W}_{\exp }$ is the expected weight. The latter was calculated with a theoretical growth curve obtained from the regression between W and SL of the entire set of data. This index allows observing weight deviations of a certain length from the expected weight calculated with the species growth curve; values higher than 1 should characterize good nutritional condition for larvae, and lower values would reflect a poorer condition (Ciechomski et al. 1986). Condition indices between areas were compared for larvae ranged from 11 to $18 \mathrm{~mm}$ SL. Statistical comparisons using a non parametric Kruskal-Wallis analysis of variance were performed.

A Principal Component Analysis (PCA) was also used to determine if morphological differences could be detected among larvae from the three studied areas. Analyses were performed for larvae ranged from 11 to $18 \mathrm{~mm}$ SL using Statsoft Statistica 6.0. In order to remove the effect of size, morphometric variables and weight employed in the PCA were normalized according to Lleonart et al. (2000) and Catalán (2003) to a reference length of $14 \mathrm{~mm}$ SL.

\section{Results}

\section{Growth}

The relationship between dry weight and standard length of anchovy larvae including the entire set of data between $11-18 \mathrm{~mm}$ SL was $W=0.13 \times \mathrm{SL}^{3.24}\left(\mathrm{n}=356, \mathrm{R}^{2}=0.99, P\right.$ $<0.001$ ). Growth curve slopes and $\log _{\mathrm{e}}$-transformed growth curves of larvae from the three areas are shown 


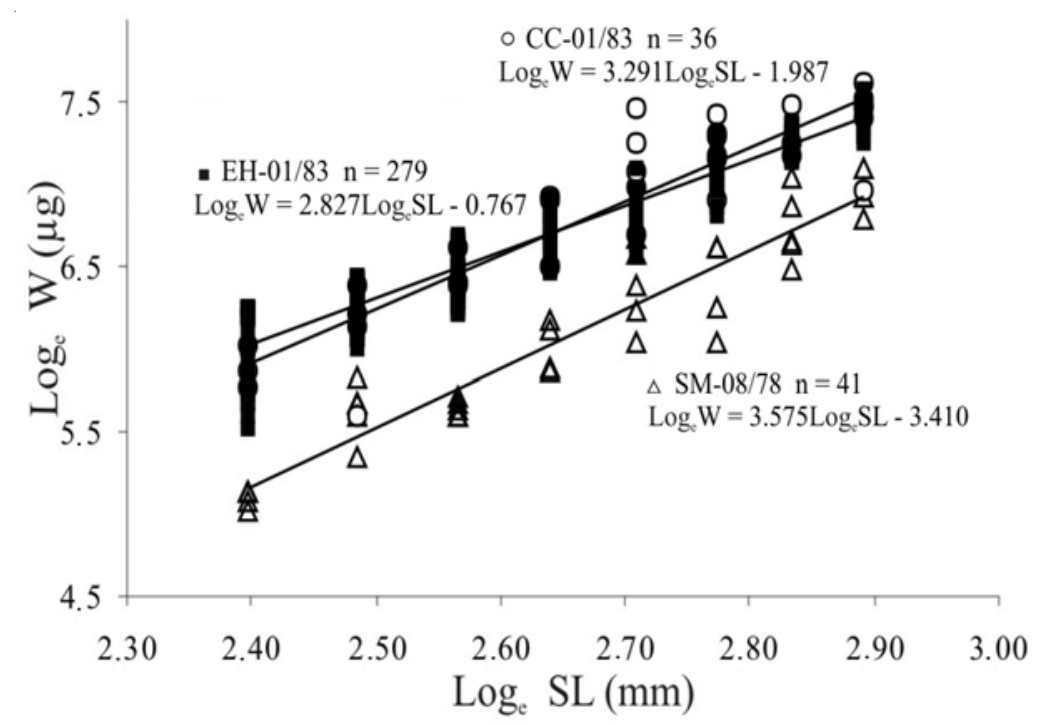

Figure 3

\section{Relationships of $\log _{\mathrm{e}} \mathrm{W}$ on $\log _{\mathrm{e}} \mathrm{SL}$ for Engraulis anchoita larvae between 11-18 mm SL from SM-08/78 ( $\Delta$ ) to El Rincón area, CC-01/83 (O) to Outer-shelf area and EH-01/83 ( $\square$ ) to Península Valdés area}

Relación del $\log _{\mathrm{e}} \mathrm{W}$ sobre y el $\log _{\mathrm{e}} \mathrm{SL}$ para larvas de Engraulis anchoita entre 11-18 mm LS de SM-08/78 ( $\left.\Delta\right)$ al área de El Rincón, CC-01/83 (O) al área de la Plataforma Continental y EH-01/83 (ם) al área de Península Valdés

in Table 1 and Fig. 3. Comparing growth curves from El Rincón (SM-08/78) and Península Valdés (EH-01/83), it was observed that the slope obtained for the former was steeper than the corresponding for the latter $(P<0.001)$. Besides, no differences between larvae growth curve slope from El Rincón and Outer-shelf (CC-01/83) were found $(P>0.264)$, but curve intercept for El Rincón was lower $(P<0.001)$. In fact, weight of any anchovy larvae 11 to $18 \mathrm{~mm}$ SL from El Rincón represented 45-59\% of the weight of a larva from Outer-shelf. Finally, no differences in growth curves between Outer-shelf area and Península Valdés were observed $(P>0.096)$.

\section{Condition indices}

Mean and median values of Fulton (FCI) and Le Cren condition indices (LCCI) are shown in Table 1. Both indices estimated for El Rincón (SM-08/78) were significantly lower than the values obtained for the other areas $(P<0.001)$. On the other hand, no differences between Península Valdés (EH-01/83) and Outer-shelf area (CC-01/83) were observed $(P>0.5)$. Mean LCCI values obtained for larvae from El Rincón were lower than 1 indicating a deficient nutritional condition of larvae inhabiting this area. On the other hand, larvae from Península Valdés and Outer-shelf area showed mean LCCI values higher than 1.

\section{Multivariate analysis}

Plots of head length (HL), body depth at cleithrum (BDC), body depth at the anus (BDA) and eye diameter (ED) against standard length (SL) from larvae captured in the three studied areas are shown in Fig. 4.

In general, with the exception of ED, values of morphometrical variables at a certain SL of larvae from El Rincón (SM-08/78) were lower than those obtained for the other areas.

Multivariate analyses were performed on normalized variables. The first two principal components of the PCA explained $77.5 \%$ of total variance (Table 2). PC1 explained the $59.6 \%$ of total variance and represented the overall pattern of the morphometric indices; it could be interpreted as an index of body depth. Though all indices were correlated to PC1, weight and body depth were most closely related with it. PC2 explained the $17.9 \%$ of total variance and was a contrast between $\mathrm{W}$ and ED (Table 2).

The graphical representation of the factor scores of PC1 and PC2 obtained for each area is presented in Fig. 5a. Most larvae from El Rincón (SM-08/78) are splitting from those collected in the other two areas (encircled areas in Fig. 5). PC1 separates individuals from El Rincón 

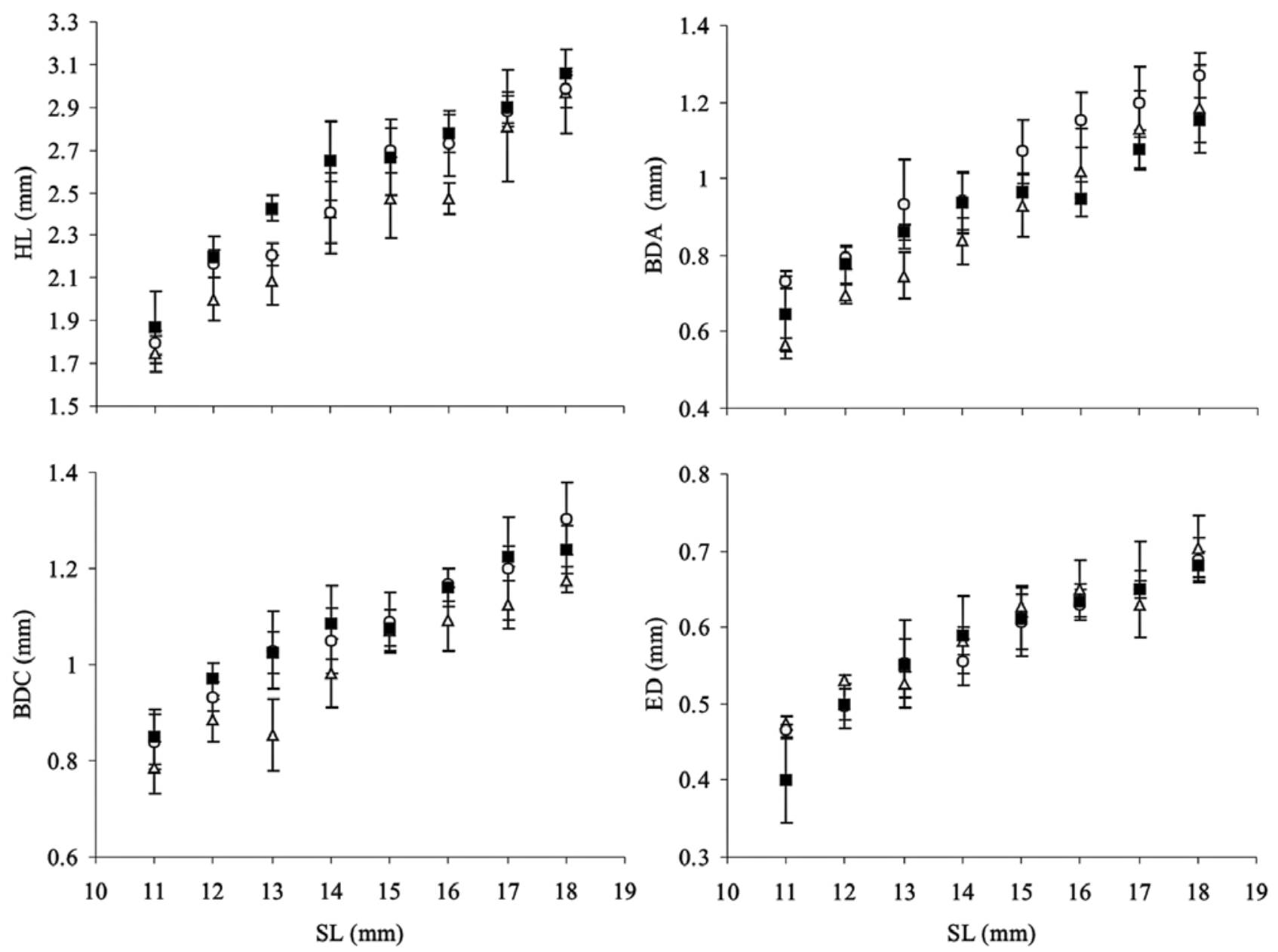

Figure 4

Relationship of morphometrical variables on standard length and SD whiskers for Engraulis anchoita larvae between 11-18 mm SL from SM-08/78 $(\Delta)$ to El Rincón area, CC-01/83 (O) to Outer-shelf area and EH-01/83 ( $\square$ ) to Península Valdés area. SL: standard length, HL: head length, BDC: body depth at cleitrum, BDA: body depth at the anus and ED: eye diameter

Relación de las variables morfométricas con la longitud estándar y su desviación estándar para larvas de Engraulis anchoita entre 11-18 mm LS provenientes de SM-08/78 $(\Delta)$ al área de El Rincón, CC-01/83 (O) al área de la Plataforma Continental y EH-01/83 (ם) al área de Península Valdés. SL: longitud estándar, HL: longitud de de la cabeza, BDC: anchura del cuerpo a nivel del cleitro, BDA: anchura del cuerpo a nivel del ano y ED: diámetro del ojo

that exhibit a slender body and lower weight and PC2 separates those with bigger eyes in relation to the rest of the body.

A second PCA was performed on normalized variables excluding weight. The first two principal components of the PCA explained $77.9 \%$ of total variance (Table 3). PC1 explained the $57.3 \%$ of total variance and represented the overall pattern of the morphometric indices. Body depths were most closely related with PC1. PC2 explained the $20.6 \%$ of total variance, most of this variance was explained by opposite trends between HL and ED (Table 3).

The graphical representation of the factor scores of PC1 and PC2 obtained for each area is showed in Fig. $5 \mathrm{~b}$. As in the previous case, larvae from El Rincón (SM08/78) are somehow splitting from larvae obtained in the other two regions. PC1 separates individuals from El Rincón that exhibit a slender body and PC2 separates those with bigger eyes. 
Table 2

Results from the PCA on larvae between 11-18 mm SL, eigenvectors (Evc), eigenvalues, percent of the variance explained of the original data set $\left(\mathbf{r}^{2}\right)$, and correlation $(r)$ of the original variables with the first two principal components, based upon five morphometrical variables: head length (HL), body depth at cleitrum (BDC), body depth at the anus (BDA), eye diameter

(ED) and total weight (W)

Resultados del análisis de componentes principales sobre larvas de entre 11-18 mm LS, autovectores (Evc), autovalores, porcentaje de varianza explicada del conjunto original de datos $\left(\mathrm{r}^{2}\right)$, y correlación (r) de las variables originales con los dos primeros componentes principales, basado en cinco variables morfométricas: longitud de la cabeza (HL), anchura del cuerpo a nivel del cleitro (BDC), anchura del cuerpo a nivel del ano (BDA), diámetro del ojo (ED) y peso total (W)

\begin{tabular}{lcccc}
\hline & \multicolumn{2}{c}{ PC 1 } & \multicolumn{2}{c}{ PC 2 } \\
& $\mathrm{R}$ & Evc & $\mathrm{r}$ & $\mathrm{Evc}$ \\
\hline $\mathrm{HL}$ & -0.756 & -0.438 & 0.080 & 0.085 \\
$\mathrm{BDC}$ & -0.866 & -0.501 & 0.029 & 0.030 \\
$\mathrm{BDA}$ & -0.842 & -0.488 & 0.080 & 0.084 \\
$\mathrm{ED}$ & -0.422 & -0.244 & -0.902 & -0.954 \\
$\mathrm{~W}$ & -0.879 & -0.509 & 0.259 & 0.274 \\
Eigenvalue & 2.980 & & 0.895 & \\
$\mathrm{r}^{2}$ & 59.6 & & 17.9 & \\
\hline
\end{tabular}

Table 3

Results from the PCA on larvae between 11-18 mm SL, the eigenvectors (Evc), eigenvalues, percent of the variance explained of the original data set $\left(r^{2}\right)$, and correlation ( $\left.r\right)$ of the original variables with the first two principal components, based upon four morphometrical variables: head length (HL), body depth at cleitrum (BDC), body depth at the anus (BDA) and eye diameter (ED)

Resultados del análisis de componentes principales sobre larvas de entre 11-18 mm LS, autovectores (Evc), autovalores, porcentaje de varianza explicada del conjunto original de datos $\left(\mathrm{r}^{2}\right)$, y correlación (r) de las variables originales con los dos primeros componentes principales, basado en cuatro variables morfométricas: longitud de la cabeza (HL), anchura del cuerpo a nivel del cleitro (BDC), anchura del cuerpo a nivel del ano (BDA) y diámetro del ojo (ED)

\begin{tabular}{lccrr}
\hline & \multicolumn{2}{c}{ PC 1 } & \multicolumn{2}{c}{ PC 2 } \\
& $\mathrm{R}$ & Evc & $\mathrm{r}$ & Evc \\
\hline $\mathrm{HL}$ & 0.764 & 0.504 & -0.233 & -0.257 \\
$\mathrm{BDC}$ & 0.874 & 0.577 & -0.163 & -0.180 \\
$\mathrm{BDA}$ & 0.818 & 0.540 & -0.154 & -0.170 \\
$\mathrm{ED}$ & 0.528 & 0.348 & 0.848 & 0.934 \\
Eigenvalue & 2.294 & & 0.823 & \\
$\mathrm{r}^{2}$ & 57.3 & & 20.6 & \\
\hline
\end{tabular}



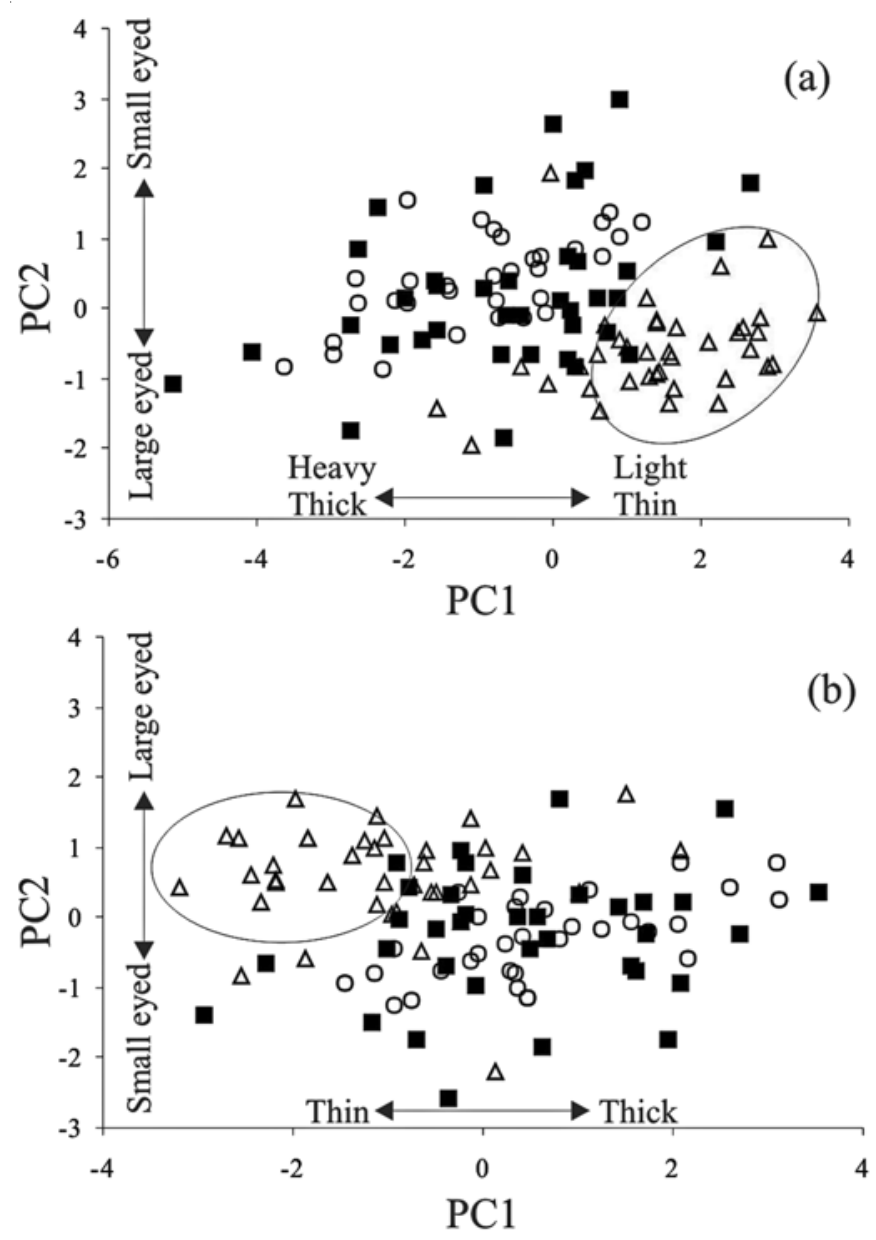

Figure 5

Scatterplot of PC2 on PC1 for Engraulis anchoita larvae between 11-18 mm SL of SM-08/78 ( $\Delta$ ), El Rincón area; CC-01/83 (O), Outer-shelf area and EH-01/83 (ם), Península Valdés area. (a) PCA based upon normalized morphometrical variables and total weight. (b) PCA based upon normalized morphometrical variables only

Representación de los dos primeros componentes principales PC1 y PC2 para larvas de Engraulis anchoita entre 11-18 mm LS provenientes de SM-08/78 ( $\Delta$ ), área El Rincón; CC-01/83 (O), área de la Plataforma Continental y EH-01/83 (ם), área de Península Valdés. (a) PCA basado en variables morfométricas normalizadas y el peso total. (b) PCA basado únicamente en variables morfométricas

\section{Discussion}

El Rincón had been characterized as a highly productive area, playing a paramount role as nursery grounds for fishes (Acha et al. 2004). However, sampled larvae from El Rincón showed a steeper growth curve slope but had lower weight, and thus low condition indices, in comparison with specimens from the other areas. During the 1978-1988 periods the highest anchovy larvae density was detected in spring of 1978 in the Northern population (Sánchez 1995). As a consequence of the high anchovy larvae abundance in El Rincón area, it is possible that density-dependent mechanisms could have operated. Those high densities of anchovy larvae could lead to an enhancement of intra-specific competition due to limiting food sources. Some authors (Hoverkamp 1992, Horwood et al. 2000) have suggested that, in plaice larvae populations, these regulation mechanisms lead to high density-dependent mortality that would select high growth rate individuals. Beverton (1995) has suggested that species which become spatially concentrated at a vulnerable stage of their life history are likely to be subject 
to stronger density-dependent forces than those species that do not concentrate. Anchovy eggs, larvae and juveniles tend to concentrate to some extent in coastal regions. Therefore, even though it seems a contradiction that larvae with higher growth rate showed low condition indices, during early development food is converted into growth rather than into energy stores, thus starvation resistance is sacrificed for growth (Powell \& Chester 1985). Our results suggest that, even though it is expected that an environment characterized by high secondary production represents an optimal background for larvae survival, a balance between densities of well-dispersed larvae and aggregated food organisms might be needed (McGurk 1986).

Temperature is usually considered as the main abiotic factor that modify larval growth rate (Crecco \& Savoy 1985, Rutherford \& Houde 1995). Even though it is usually assumed that higher temperatures are related to higher growth rates, in this work no relationship was found between these two variables. In addition, previous studies in Northern population anchovy larvae growth showed no relationship between growth rate and water temperature when comparing larvae captured in different seasons (Leonarduzzi et al. in press).

The high values of condition indices found in Outershelf and Península Valdés area are expected because both frontal areas are characterized by high primary and secondary productivity (Sabatini \& Martos 2002, Marrari et al. 2004). It is in those areas where high densities of nauplii copepods of species that represent the principal feeding items of anchovy larvae are found (Viñas \& Ramírez 1996). Sieg (1997) and Clemmesen et al. (1997) suggested that higher condition indices found in Península Valdés could be due to the presence of invertebrate predators in Patagonian cold waters which capture selectively emaciated larvae before they had reached the level of «starved» individuals. In contrast, in Brazilian waters, larvae could be more susceptible to absence of food, rather than predation, as a result of a higher metabolic rate due to high temperatures.

Multivariate analysis employing morphometrical variables and weight also allowed finding differences between nutritional conditions of larvae from the three studied areas. The principal component analysis (PCA) separated larvae from El Rincón from larvae captured in the other areas. Nevertheless, a continuous gradient was observed in the distribution of the cases on the factorial plot, showing the individual variability of larvae condition in the wild.

When weight was included in the PCA, larvae from El Rincón showed slender bodies with relatively bigger eyes and lower weights than larvae from other nursery areas. We could assume that larvae from El Rincón had a lower condition. As eye diameter is a morphometric character that does not shrink in response to starvation, starved larvae have larger eyes in relation to the rest of the body (McGurk 1985). The second analysis, which excluded weight, showed similar results, since larvae from El Rincón splits from larvae from other cruises in the plot and were characterized by slender bodies and relatively big eyes. These results and the fact that the variance explained by PC1 and PC2 was also high (77.9\%) demonstrate that weight could be excluded from analysis and thus facilitate the procedures and shorten larvae processing time.

Multivariate analysis is one of the best techniques that allow the study of several variables from individuals as a whole to determine affinities between those individuals. McGurk (1985) stated that only PCA satisfies the requirements of the ideal morphometric factor: sizeindependence; biological meaning and orthogonality. Another advantage of this technique is that it opens the possibility of assessing wild larvae where nutrition and development is unknown (Cunha et al. 2003).

The influence of size due to allometric growth should be eliminated to guaranty that shape variations are only reflecting nutritional status of larvae. This could be achieved by restricting analysis to a size group (Powell \& Chester 1985), by normalization methods (Lleonart et al. 2000) or discarding the first principal component (Ferron \& Leggett 1994) which normally represents size because all the characters are positively correlated with this component. In order to diminish allometric growth effect, our morphometrical variables were restricted to a small size range and normalized. Normalization of morphometrical variables prior to PCA allowed the employment of first principal component in the analysis which incorporates information of larvae shape (Lleonart et al. 2000).

Finally, it becomes evident that frontal zones play a key role in ecological processes of the ocean (Acha et al. 2004), allowing an exceptionally large primary production (Carreto et al. 1986), offering adequate feeding and/or reproductive habitats for nektonic species (Viñas et al. 2002) and acting as retention areas for larvae. Nevertheless, they also might represent a disadvantageous zone because of abundance enhancement of potential predators for E. anchoita (Mianzan \& Guerrero 2000, Alvarez-Colombo et al. 2003).

In order to elucidate the influence of frontal systems on anchovy larvae nutritional condition further studies taking into account both biological and oceanographical 
parameters are required. Viñas \& Ramírez (1996) provided evidence indicating that transitional and stratified sectors of the Península Valdés frontal system provide better feeding conditions for survival and growth of anchovy larvae than homogeneous mixed waters. In this regard, it would be necessary a reduction in the study scale and a detailed vertical sampling to obtain material from the different water masses that comprise the frontal systems herein studied.

It is also highly recommended the employment of additional condition indicators (e.g. biochemical or histological) together with morphometrics, to get an overall picture of the starvation process in order to determine better nursery areas for $E$. anchoita larvae in the Argentine Sea.

In conclusion, results herein presented showed that the use of morphometrical variables and weight represent simple and easy to assess tools, that allow finding differences in growth rate and nutritional condition among anchovy larvae collected in areas characterized by dissimilar oceanographic scenarios.

\section{Acknowledgments}

We wish to thank Marcela De Falco for her valuable comments on the manuscript, Anibal Aubone for his help with the data processing and CITEP authorities for the loan of the electrobalance. This work was partially supported by the Agencia Nacional de Promoción Científica y Técnica: ANPCyT (BID 1201/OC-AR - PICT 03-15227). Our thanks are also extended to four anonymous reviewers for their improvements and useful suggestions. This is INIDEP contribution $N^{\circ} 1557$.

\section{Literature cited}

Acha EM, HW Mianzan, RA Guerrero, M Favero \& J Bava. 2004. Marine fronts at the continental shelves of austral South America physical and ecological processes. Journal of Marine Systems 44: 83-105.

Alvarez-Colombo G, H Mianzan \& A Madirolas. 2003. Acoustic characterization of gelatinous-plankton aggregations: four case studies from the Argentine Continental shelf. ICES Journal of Marine Science 60: 650657.

Bailey KM \& ED Houde. 1989. Predation on eggs and larvae of marine fishes and the recruit problem. Advances in Marine Biology 25: 1-83.

Beverton RJH. 1995. Spatial limitation of population size; the concentration hypothesis. Netherlands Journal of Sea Research 34: 1-6.

Carreto JI, HR Benavides, RM Negri \& PD Glorioso. 1986. Toxic red-tide in the Argentine sea. Phytoplankton distribution and survival of the toxic dinoflagellate
Gonyaulax excavata in a frontal area. Journal of Plankton Research 8: 15-28.

Catalán IA. 2003. Condition indices and their relationship with environmental factors in fish larvae. Tesis Doctoral. Universitat de Barcelona, Barcelona, 265 pp.

Ciechomski JD \& RP Sánchez. 1984. Field estimates of embryonic mortality of Southwest Atlantic anchovy (Engraulis anchoita). Meeresforschung / Reports on Marine Research 30: 172-187.

Ciechomski JD, RP Sánchez, G Alespeiti \& H Regidor. 1986. Estudio sobre el crecimiento en peso y factor de condición en larvas de anchoíta, Engraulis anchoita Hubbs \& Marini. Variaciones regionales, estacionales y anuales. Revista de Investigación y Desarrollo Pesquero 5: 183-193.

Clemmesen CM, RP Sánchez \& C Wongtschowski. 1997. A regional comparison of nutritional condition of SW Atlantic anchovy larvae (Engraulis anchoita) based on RNA/DNA ratios. Archive of Fishery and Marine Research 45: 17-43.

Crecco VA \& TF Savoy. 1985. Effects of biotic and abiotic factors on growth and relative survival of young American shad, Alosa sapidissima, in the Connecticut River. Canadian Journal of Fisheries and Aquatic Sciences 42: 1640-1648.

Cunha I, F Saborido-Rey \& M Planas. 2003. Use of multivariate analysis to assess the nutritional condition of fish larvae from nucleic acids and protein content. The Biological Bulletin 204: 339-349.

Ehrlich KF, JHS Blaxter \& R Pemberton. 1976. Morphological and histological changes during the growth and starvation of herring and plaice larvae. Marine Biology 35: $105-118$.

Ferron A \& WC Leggett. 1994. An appraisal of condition measures for marine fish larvae. Advances in Marine Biology 30: 217-303.

Frank KT \& JK McRuer. 1989. Nutritional status of fieldcollected haddock (Melanogrammus aeglefinus) larvae from Southwestern Nova Scotia: an assessment based on morphometric and vertical distribution data. Canadian Journal of Fisheries and Aquatic Sciences 46: 125-133.

Glorioso PD. 1987. Temperature distribution related to shelfsea fronts on the Patagonian shelf. Continental Shelf Research 7: 27-34.

Håkanson JL. 1989. Analysis of lipid components for determining the condition of anchovy larvae, Engraulis mordax. Marine Biology 102: 143-151.

Hansen JE, MB Cousseau \& DL Gru. 1984. Características poblacionales de la anchoíta (Engraulis anchoita) del Mar Argentino. Parte I. El largo medio al primer año de vida, crecimiento y mortalidad. Revista de Investigación y Desarrollo Pesquero 4: 21-48.

Hjort J. 1914. Fluctuations in the great fisheries of northern Europe viewed in the light of biological researches. Rapports et Procès-Verbaux des Réunions, Conseil international pour l'Exploration de la Mer 20: 1-128.

Horwood J, DH Cushing \& T Wyatt. 2000. Planktonic determination of variability and sustainability of fisheries. 
Journal of Plankton Research 22: 1419-1422.

Houde ED. 2008. Emerging from Hjort's Shadow. Journal of Northwest Atlantic Fishery Science 41: 53-70.

Hoverkamp F. 1992. Growth-dependent mortality of larval plaice Pleuronectes platessa in the North Sea. Marine Ecology Progress Series 82: 95-101.

Leonarduzzi E, DR Brown \& RP Sánchez. In press. Seasonal variations in the growth of larvae of anchovy (Engraulis anchoita) in the coastal Argentine shelf. Scientia Marina [in press].

Lleonart J, J Salat \& GJ Torres. 2000. Removing allometric effects of body size in morphological analysis. Journal of Theoretical Biology 205: 85-93.

Lucas AJ, RA Guerrero, HW Mianzán, ME Acha \& CA Lasta. 2005. Coastal oceanographic regimes of the Northern Argentine Continental Shelf (34-43으. Estuarine, Coastal and Shelf Science 65: 405-420.

Mann KH \& JRN Lazier. 1996. Dynamics of marine ecosystems. Biological-physical interactions in the oceans, 394 pp. Blackwell Science, Cambridge.

Marrari M, MD Viñas, P Martos \& D Hernández. 2004. Spatial patterns of mesozooplankton distribution in the

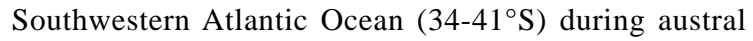
spring: Relationship with the hydrographic conditions. ICES Journal of Marine Science 61: 667-679.

Martos P \& MC Piccolo. 1988. Hydrography of the Argentine continental shelf between $38^{\circ}$ and $42^{\circ}$ S. Continental Shelf Research 8: 1043-1056.

McFadzen IRB, SH Coombs \& NC Halliday. 1997. Histological indices of the nutritional condition of sardine, Sardina pilchardus (Walbaum) larvae off the north coast of Spain. Journal of Experimental Marine Biology and Ecology 212: 239-258.

McGurk MD. 1985. Multivariate analysis of morphometry and dry weight of Pacific herring larvae. Marine Biology 86: $1-11$.

McGurk MD. 1986. Natural mortality of marine pelagic fish eggs and larvae: role of spatial patchiness. Marine Ecology Progress Series 34: 227-242.

Mianzan HW \& RA Guerrero. 2000. Environmental patterns and biomass distribution of gelatinous macrozooplankton. Three study cases in the Southwestern Atlantic Ocean. Scientia Marina 64(Suppl. 1): 215-224.

O’Connell CP. 1976. Histological criteria for diagnosing the starving condition in early post yolk sac larvae of the northern anchovy, Engraulis mordax Girard. Journal of Experimental Marine Biology and Ecology 25: 285-312.

Olson DB. 2002. Biophysical dynamics of ocean fronts. In: Robinson AR, JJ McCarthy \& BJ Rothschild (eds). The Sea 12. Biological-physical interactions in the sea, pp. 187-
218, Wiley, New York.

Pájaro M. 1998. El canibalismo como mecanismo regulador denso-dependiente de mortalidad natural en la anchoíta argentina (Engraulis anchoita). Su relación con las estrategias reproductivas de la especie. Tesis Doctoral. Universidad Nacional de Mar del Plata, Mar del Plata, 273 pp.

Powell AB \& AJ Chester. 1985. Morphometric indices of nutritional condition and sensitivity to starvation of spot larvae. Transactions of the American Fisheries Society 114: 338-347.

Rutherford ES \& ED Houde. 1995. The influence of temperature on cohort-specific growth, survival, and recruitment of the striped bass, Morone saxatilis, larvae in Chesapeake Bay. Fishery Bulletin 93: 315-332.

Sabatini M \& P Martos. 2002. Mesozooplankton features in a frontal area off northern patagonia (Argentina) during spring 1995 and 1998. Scientia Marina 66: 215-232.

Sánchez RP. 1995. Patrones de distribución espacio-temporal de los estadios embrionarios y larvales de la anchoíta (Engraulis anchoita Hubbs and Marini) a micro y macro escala, su relación con la supervivencia y el reclutamiento. Tesis Doctoral. Universidad Nacional de Buenos Aires, Buenos Aires, 672 pp.

Sánchez RP \& JD Ciechomski. 1995. Spawning and nursery grounds of pelagic fish species in the sea-shelf off Argentina and adjacent areas. Scientia Marina 59: 455-478.

Sánchez RP, M Pájaro \& GJ Macchi. 1996. The application of the daily egg production method to the assessment of the SW Atlantic anchovy, (Engraulis anchoita), spawning biomass off Argentina. International Council for the Exploration of the Sea CM 1996/H: 1-29.

Sieg A. 1998. A study on the histological classification of the in situ-nutritional condition of larval South-west Atlantic anchovy, Engraulis anchoita Hubbs and Marini, 1935. Archive of Fishery and Marine Research 46: 19-36.

Theilacker G. 1978. Effect of starvation on the histological and morphological characteristics of jack mackerel, Trachurus symmetricus larvae. Fishery Bulletin 76: 403414.

Viñas MD \& FC Ramírez. 1996. Gut analysis of first-feeding anchovy larvae from Patagonian spawning area in relation to food availability. Archive of Fishery and Marine Research 43: 231-256.

Viñas MD, RM Negri, FC Ramírez \& D Hernández. 2002. Zooplankton assemblages and hydrography in the spawning area of anchovy (Engraulis anchoita) off Río de la Plata estuary (Argentina, Uruguay). Marine and Freshwater Research 53(6): 1031-1043. 